\title{
Assessing Surgical Risk in Patients with Liver Cancer in Emam Khomeini Hospital from 2019 to 2020
}

\author{
Maryam Esmaeili ${ }^{1}$, Mitra Zandi ${ }^{2}$ \\ 1. MSc Student of Critical Nursing Care, Student Research Committee, School of Nursing and Midwifery, Shahid Beheshti \\ University of Medical Sciences, Tehran, Iran. ORCID ID: 0000-0002-6595-0790 \\ 2. Assistant Professor, Nursing and Midvivery Faculty, Shahid Beheshti University of Medical Sciences, Tehran, Iran., \\ (Corresponding Author), Tel: 021-88202511, Email: Mitra.zandi@yahoo.com, ORCID ID: 0000-0002-7395-0280
}

\begin{abstract}
Background and Aim: Physical and psychological outcomes are one of the most important problems in patients with liver cancer, which can affect new patients' ability and their quality of life. Regarding the necessity of reducing and eliminating these consequences, the study was conducted to investigate the consequences of surgery in patients with liver cancer.

Materials and Methods: This descriptive study was performed on 53 patients with liver cancer referred to Imam Khomeini Hospital Complex in Tehran using the available sampling method from November 2019 to June 2020. During the study, Functional Cancer Questionnaire, Hospital Anxiety, and Depression Scale, Fatigue Severity, Edmonton Symptom Evaluation, and Demographic Characteristics were used in two stages (before and one month after the treatment). Data were analyzed using SPSS 21, descriptive statistics, Pair T-test, and correlation.

Results: Fatigue, loss of appetite, pain, anxiety, sleep disturbances, and other problems were significantly increased in comparison with the pre-treatment period $(p<0.05)$. There was a significant relationship between these outcomes and the quality of life of the patients $(\mathrm{p}<0.001)$.

Conclusion: Patients with cancer have experienced moderate to severe physical, and psychological consequences. Considering the impact of these outcomes on the survival and quality of life, one of the important tasks in the cancer department is, to prevent, identify, and control the complications of liver cancer treatment.
\end{abstract}

Keywords: Liver cancer, Consequences, Anxiety, Depression, Surgery, Health-related quality of life.

Received: July 28, $2019 \quad$ Accepted: Dec 20, 2019

How to cite the article: Maryam Esmaeili, Mitra Zandi. Assessing surgical risk in patients with Liver Cancer in Emam Khomeini Hospital from 2019 to 2020. SJKU 2020;25(2):120-131.

Copyright (C) 2018 the Author (s). Published by Kurdistan University of Medical Sciences. This is an open access article distributed under the terms of the Creative Commons Attribution-Non Commercial License 4.0 (CCBYNC), where it is permissible to download, share, remix, transform, and buildup the work provided it is properly cited. The work cannot be used commercially without permission from the journal 


\section{بررسى ييامدهاى ناشى از روش جراحى در بيماران مبتلا به سرطان كبد مراجعه كننده به

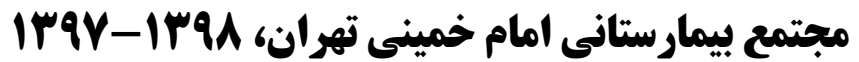



جִكيله

مقدمه و هدف: بيامدهاى جسمى و روانشناختى از مهمترين مشكلات بيماران مبتلا به سرطان كبد است كه با تأثير بـر توانايى و كيفيت زندگى بيماران بحرانهاى تازهاى در آنها ايجاد مىنمايد. با توجه به ضرورت كاهش و رفع اين بيامدهـا، مطالعهـ بـا هـدف بررسى بيامدهاى ناشى از روش جراحى در بيماران مبتلا به سرطان كبد انجام شد. مواد و روشها: اين مطالعه توصيفى بر روى لاه بيمار مبتلا به سرطان كبد مراجعه كننده بـه مجتمـع بيمارستانى امـام خمينى(ره)

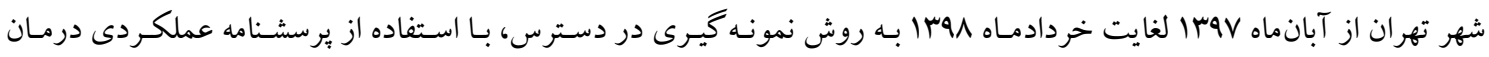


مرحله (قبل و يكك ماه بعد از درمان) انجام شد. جهت روايى ابزارها به مطالعات قبلى استناد و يايايى آنهـا نيـز بـا اسـتفاده از آزمـون

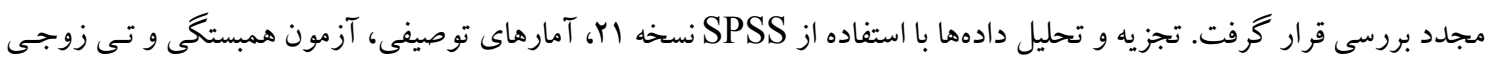
انجام شد. يافته ها: شدت خستخى، بى اشتهايى، درد، اضطر اب، اختلالات خواب و ساير مشكلات بعد از درمـان در مقايسـه بـا قبـل از درمـان افزايش جشمگيرى داشتند (ه • ••>p). رابط معنىدارى ميان اين بيامدها با وضعيت عملكردى بيماران ( ( • • > p) بود. نتيجهه كيرى: بيماران مبتلا به سرطان كبد بيامدهاى جسمى و روانشناختى رادر حد متوسط تا شديد تجربه كردهانـد. بـا توجـه بـه تأثير اين بيامدها بر زندگى و ميزان بقاء بيماران، يكى از وظايف مهم و كليدى در بخشهاى سرطان، بيشخيرى، شناسـايى و كنترل عوارض ناشى از درمان سرطان كبد است. كلمات كليدى: سرطان كبد، ييامدها، اضطراب، افسردگى، جراحى، كيفيت زندگى وابسته به سلامت

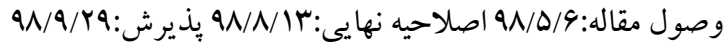




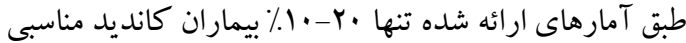
براى جراحى هستند(fاو ساو). درمان سرطان اكرجه در بسيارى از موارد منجر به بهبـودى و افـز ايش بقــاء مسى شــود ولـى در بسـيارى از مــوارد داراى ييامدهاى جسمى و روانشناختى متعددى است؛ كه مىتواند به شـكل عميقى بـر تمـام جنبـهــاى زنــــى بيمـاران تـأثير كذاشته و توانايى فرد در انجام امور فردى و اجتماعى راكـم و منجــر بــه بـروز مشـكلات فراوانـى در زمينـه اقتصـادى، اجتمـاعى، خـانوادكى شـود(Y). در واقـع سـرطان بـه عنـوان بزرگ گترين عامل استرسزاى جسمى -روانسى در نظر گرفتـه مى شود ؛كه مى تواند مشكلات زيـادى بـراى بيمـاران ايجـاد

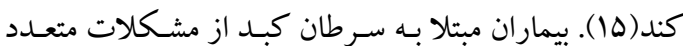
جسـمى و روانشــناختى جــون درد، خســــى، اضـطر اب، افسردگى، بى خو ابى رنج مىبرند؛ كه ناشىى از بيمـارى و يـا


از آنجايى كه مهم ترين جنبه مراقبتى در اين بيمـاران كـاهش درد، توجسه بـه وضسعيت روحسى -روانسى، افز ايش عملكـرد فيزيكى، عدم وابستخى به ديخـران و بهبـود كيفيـت زنـدكى

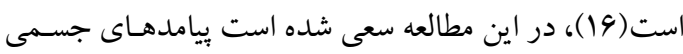
و روانشناختى ناشى از درمان بـه روش جراحسى شناسـيى و مورد ارزيابى قرار كيرند. از نتايج حاصل از اين مطالعه مسى توان در جهت ارائه مراقبتهاى استـاندارد كـه از مهـم تـرين وظايف گروه درمانى است، اسـتفاده نمـود. اهميـت كيفيـت زندكى بيماران و وضعيت سلامت آنها تا حسدى اسـت كـه قرن حاضر را قرن بهبـود كيفيـت زنـدگى و سـلامت معرفى كردهاند. متغير كيفيت زندكى وابسته به سلامت بعد از متغير ميزان بقاء به عنوان دومين متغير مهم جهت ارزيابى وضسعيت

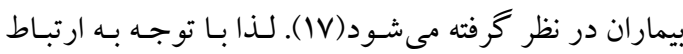
ييامدهاى جسـمى و روانشــاختى بـا وضسعيت عملكـردى و . كيفيـت زنــــى مـرتبط بـا سـلامت اتخـاذ تــابيرى جهـت كاهش اين ييامدها ضرورى به نظر مىرسد. اخرجّه مطالعات زيادى ييرامون سرطانهاى مختلف نظير معده، مرى و بسـتان وجود دارد، بُزوهش هاى زيادى بير امون جنبـهــاى مختلـف
مقدمه

سرطان يكـى از مسـائل مهـم و اساسـى مراقــت و درمـان در ايران و تمام دنيا است. در آمريكـا سـرطان بـه عنـوان دومسين عامل و در ايران سومين عامل مركَومير معرفى شـده اسـت كه سالانه بيش از ·ـ هـزار قربـانى دارد(ب-1). سـرطان كبــ

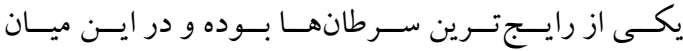
Hepatocellular Carcinoma (HCC) سـرطان اوليـه كبـد اسـت(هو \&). شـيوع آن در كشـورهـاى آسيايى و آفريقايى ه تـا · ا برابـر سـاير كشـورهـا اسـت. در آسيا ابتلا به هياتيت B و C بزر كت ترين ريسك فاكتور ابـتلا F... معرفى شـده اسـت. در حسال حاضـر حسدود HCC ميليـون نفـر بـه ايسن ويـروس مبـتلا هسـتند(V و 9). اخر جــهـ عفونتهاى ويروسى كبد در اين زمينه نقـش مهـم و اساسى دارند؛ اما فاكتورهاى مربوط به سبك زنـدكى مانــــ جـاقى، مصـرف الكـل، سـيخار را نيـز در ايـن زمينـه نبايـــ ناديــده كرفت (11-1). به دليـل افززايش اميـد بـه زنــــى در كشـور

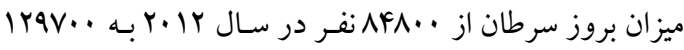

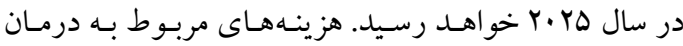
سرطان 19 برابر بيمارىهـاى قلبى اسـت( ( I). ميززان شـيوع سرطان كبد با افزايش سن افزايش مىيابد(9). ايـن ميززان در ايران در هـر دو جـسـ بـيش از دو برابـر حـد جهانى اسـت. افزايش ميززان مـركَ ناشسى از سـرطان كبــ حتسى از ميـزان توسعه كشورها بيشـتر بـوده بـه كونـهاى كـه بـراى كشـورهـا مشكلات زيادى ايجاد كرده و آنها را براى مقابله با سرطان كبد ناتوان ساخته است. در برخى موارد ابزارهاى لازم بـراى

مقابله با آن ناكافى است(11). روشهاى درمان سرطان كبد متفاوت است. اندازه، تعداد و محل تومورها، سابقه بزشكى و بيمارىهاى زمينهاى از عوامل تعيين كننده نوع درمان مىباشند. جراحى يكى از روشهاى مورد استفاده در درمان سرطان كبد است. اين روش براى تودههايى كه لو كاليزه بوده، هيج گونه شواهدى دال بر متاستاز آنها به نواحى ديگر وجود نداشته باشد و عملكرد كبدى مناسب وجود داشته باشد، استفاده مىشود. 
كبد انجام شد. نتايج حاصل از ايـن مطالعـه مسىتوانـد باعـث افزايش آكاهى كروه درمان نسـبت بـه بيامـدهـاى جسـمى و روانى در اين بيماران شده و زمينه را جهـت رفع يـا كـاهش بيامدها فراهم سازد.

مواد و روشها اين مطالعه توصيفى بر روى سه بيمـار مبـتلا بـه سـرطان كبــ مر اجعه كننده به مجتمع بيمارستانى امـام خمينسى شهر تهـران

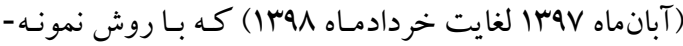
كيرى در دسـترس انتخـاب شــده بودنـــ، انجـام شــده اســـ.

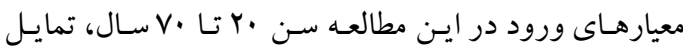
براى شركت در بزٔوهش و سـواد خوانـدن و نوشـتن (جهـت كزارش دقيقتر ييامدها توسط خود بيمار)، عدم ابتلا به سـاير سرطانها، عدم سـابقه ابـتلا بـه بيمـارىهـاى مـزمن جسـمى، روحى -روانى و سابقه مصرف داروهاى مربوط به آنها بـود. لازم بود تا جراحى اولين روش درمان در اين بيمـاران باشـــ. مركَ، عدم تمايل بيمار براى ادامه همكـارى و عـدم تكميـل كامل فرمها جزء معيـارهـاى خـروج در نظـر گرفتـه شـد. بـر اساس فرمول كو كران، ريزش • 1٪ نمونهها، ضريب اطمينـان

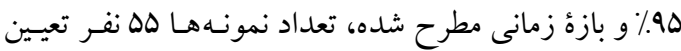
شد. فرمول كو كران به شرح زير است.

$$
n=\frac{\mathrm{N} t^{2} p q}{\mathrm{~N} d^{2}+t^{2} s^{2}}
$$

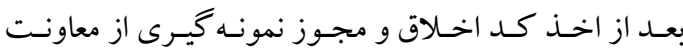

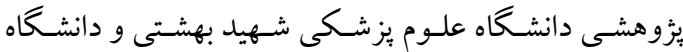
تهران، شرح اهداف ئزوهش براى بيماران، جلب همكارى و مشـار كت بيمـار ان و تكميـل فـرم رضـايتنامسه شـر كت در يُزوهش هاه بيمار مبتلا به سرطان كبد وارد مطالعه شـدند. دو مورد به دليل عدم تكميل فرمها از مطالعه خـارج شـدند و در نهايت مطالعـه بـر روى سه بيمـار انجـام شـد. جهـت بررسى يبامدهاى ناشى از روش جراحى در مبتلايان به سـرطان كبــ

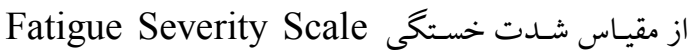

سرطان كبد به ويثزه بيامدهاى جسمى و روانشـناختى وجـود ندارد. تا جايى كه مرور مطالعاتى ما نشان مىدهـد مطالعـهاى با جنين ويز گیى و با تكيه بر بيامدهاى جسمى و روانشناختى در روش جراحى سرطان كبد انجـام نشــده اسـت. بـه عنـوان نمونه، Toro و همكاران (Y (Y Y) كيفيـت زنـدكى بيمـاران مبتلا به سرطان كبد بعـد از جراحس، شـيمىدرمـانى، امـواج راديـويى (Radio-Frequency) و زمـانى كـه هـيج نـوع درمانى براى بيمار ان انجام نشــده بـود را مـورد بررسى قـرار دادهاند. در اين مطالعـه عـود بيمـارى، اثـربخشى شـيوههـاى

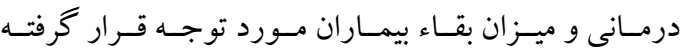

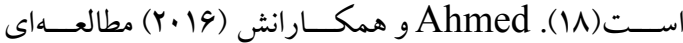
يير امون كيفيت زندكى بيمار ان مبتلا بـه سـرطان كبـد تحـت درمان به روش كمو آمبوليزاسـيون شـريانى انجـام دادنـــــدر اين بيزوهش ابز ارهـاى مـورد اسـتفاده جهـت تعيـين كيفيـت زندگى بيماران مورد ارزيابى قرار گرفته و در هايان مشخص شد HRQOL بيماران نامطلوب بـوده اسـت (19). اخركجهـ يير امون كيفيت زنـدكى بيمـار ان مبـتلا بـه سـرطان مطالعـات زيادى انجام شده اسـت؛ امـا مطالعـات انجـام شـــه در زمينـه سرطان كبد جندان گسـترده نيسـت و مطالعـات موجـود نيـز بيشتر ييرامون روش شيمى شرمانى است(Yr و •Y). مطالعاتى كه به بررسى كيفيت زندگى بيمار ان مبتلا به سرطان كبد بعد از عمل جراحى برداختـهانـــ بيشـتر بـهـ ميـزان بقـاء بيمـاران و عملكرد كبد در يكك دوره طولانى توجه داشتهانـد(س و F). مطالعاتى كه در ارتبـاط بـا بيامـدهـاى روانشـــاختى بيمـاران مبتلا به سرطان كبد باشد، بسيار محـدود اسـت( (YF ). بـر اساس مطالعـات قبلى و بـا بـهـــار گيرى برخـى مقيـاسهـا و ابزارهاى جديد و با توجه بـه شـرايط خـاص كبـد در بــدن و عملكرد مهم آن در تداوم زندگىى، توجه به مهـم تـرين جنبـه مراقبتى اين بيماران (كاهش درد، توجه به وضعيت روحسى روانى، افزايش عملكرد فيزيكى، عدم وابستخى به ديخـران و

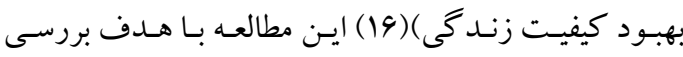
ييامدهاى ناشى از روش جراحى در بيمار ان مبتلا بـه سـرطان 
اسـت. روايسى صـورى و محتـوايى ايـن برسشــامه در ايـران توسط حسنوند و همكار انش انجام شده است(Y)، بايايى نيز از طريق آزمون مجدد مورد بررسى قرار گرفت (r=-•/A9). يرسشنامهها در طى دو مرحله، قبل و يكك مـاه بعـد از درمـان توسط بيماران تكميل شد. بعد از جمع آورى اطلاعات دادهـهـا بـا اسـتفاده از SPSS نسخه اY و آمـارهـاى توصسيفى، همبستكى و تى زوجى مورد تجزيه و تحليل قرار گرفت.

يافته ها نتايج حاصل از مطالعه نشان داد ه/ه/\% افر اد شـركت كنــده

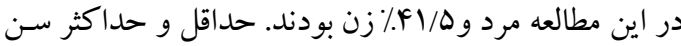
افراد شركت كننده در اين مطالعه به ترتيب rV و 99 سـال بـا

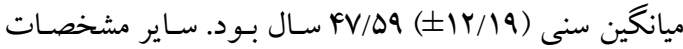
دمو گر افيكك بيماران در جدول شـماره ا آورده شـده اسـت.

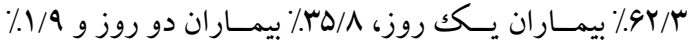
بيماران سه روز در بخش ICU بسترى بودند. ميانگين تعداد

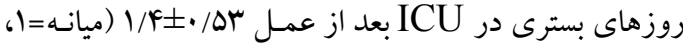

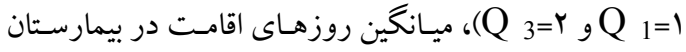
Y ييامدها قبل و بعد از درمان در جدول شماره Y خلاصسه شـده است. قبل از درمان ميانگين وضسعيت عملكردى (FACT)

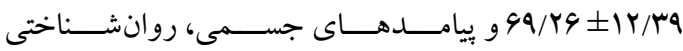

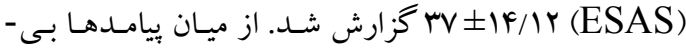
اشتهايى، تنكى نفس، تهوع و ساير مشـكلات قبل از درمـان در بيماران گز ارش نشده است. بيشـترين فراوانى مربـوط بـهـ

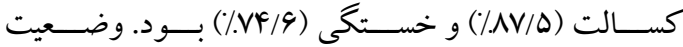

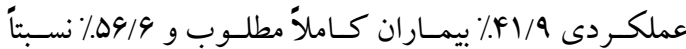

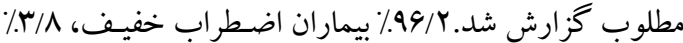

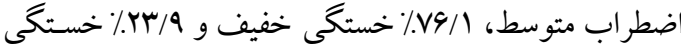
متوسط را كزارش كردند.

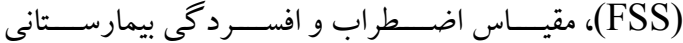
Hospital Anxiety and Depression Scale

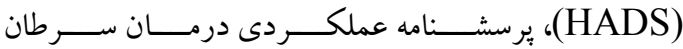
Functional Assessment Cancer Therapy Edmonton مقياس بررسى علائسم ادمونتسون)، (FACT) وSymptom Assessment System (ESAS)

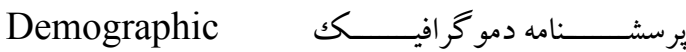
Questionnaire علائم مربوط به بيمارى و عملكرد بيمـاران مبـتلا بـه سـرطان است؛ كه در بررسى كيفيت زندگى مرتبط با سلامت در اين

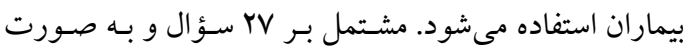

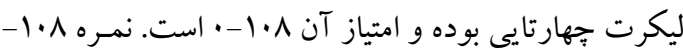
س VT وضعيت كاملاً مطلوب، MV-VY وضعيت نسبتاً مطلـوب و كمتر از وس وضعيت نامطلوب را نشان مىدهد. جهت روايسى FACT طريق آزمون مجـدد مـورد ارزيـابى قرار گرفـت (r=•/MM). ESAS بيمار ان مبتلا به سـرطان در مراحل مختلـف اسـت. داراى ده

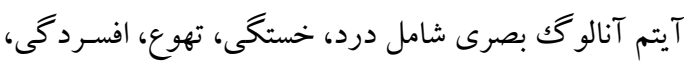
اضطراب، كسالت، اشتها، حس خوب بودن و تنكى نفس و ساير مشكلات است. به هر آيتم نمره · ا- · تعلق مسى گيرد. جهت روايى به مطالعه خليلى و همكار انش اسـتناد شـد (1) و يايايى آن از طريق آزمون مجدد (r=/V9) ارزيـابى گرديـد. HADS

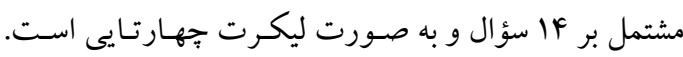

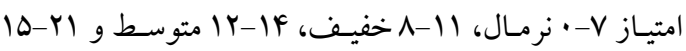

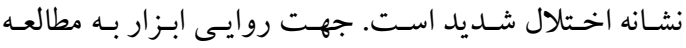



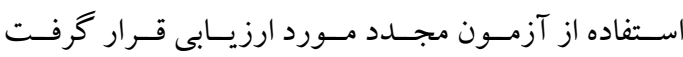
FSS . (r=•/9F) حاوى 9 سؤ ال و به صورت ليكرت Vتايى است. دامنه امتيـاز شدت خستخى V-1 و نمره بيشتر نشاندهنده خستكى بيشتر 
جدول ا. توزيع فراوانى ويز كى هاى دمو كر افيك در بيماران مبتلا به سرطان كبد تحت درمان با عمل جراحى

\begin{tabular}{|c|c|c|}
\hline فراوانى (٪) & & متغير \\
\hline IV $(r Y / I)$ & Fl-l-r. & كروههاى سنى \\
\hline$r q(\Delta F / V)$ & . 91-4 سال & \\
\hline$V(I r / Y)$ & •^-1اء سال & \\
\hline$\mu^{\prime}(\Delta \Lambda / \Delta)$ & مرد & جنس \\
\hline$r Y(F \mid / Q)$ & زن & \\
\hline$r q(\Delta F / V)$ & زير دييلم & تحصيلات \\
\hline$Y F(F \Delta / \Gamma)$ & بالاى دييلم & \\
\hline$F(V / \Delta)$ & مجرد & تأهل \\
\hline FV $(M / V)$ & متأهل & \\
\hline$r(r / \Lambda)$ & مطلقه / ييوه & \\
\hline$r \cdot(r V / V)$ & A & شدت بيمارى ا"* \\
\hline$r \Delta(F V / r)$ & B & \\
\hline$\wedge(1 \Delta / Y)$ & $\mathbf{C}$ & \\
\hline$M(Y Y / G)$ & كافى & در آمد ז* \\
\hline$F \mid(W / F)$ & نافى & \\
\hline
\end{tabular}

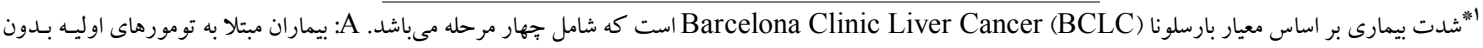

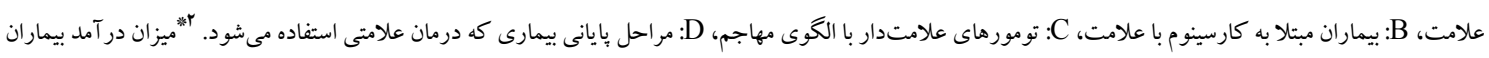
بر اساس خود اظهارى بيمار ان دستبندى شده است.

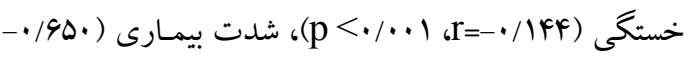

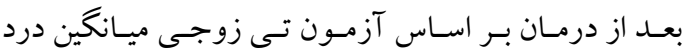

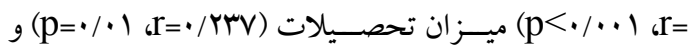

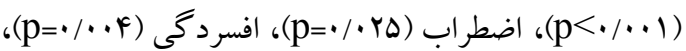



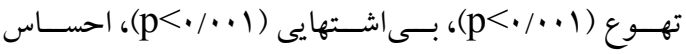

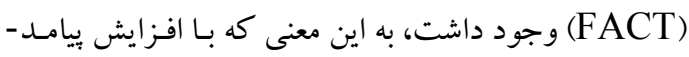
كسالت (p)

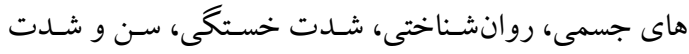

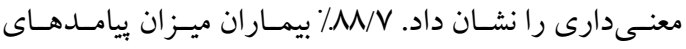

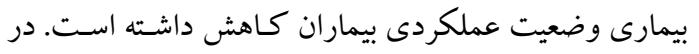

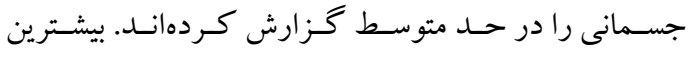

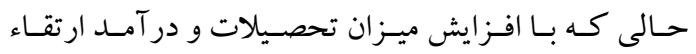

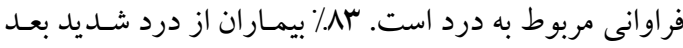
وضعيت عملكردى بيمـاران مشـاهده مسى شـود. ارتبـاط ميـان

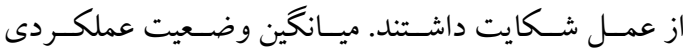

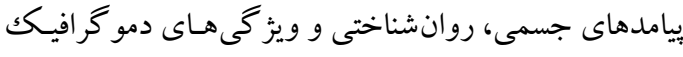
كــاهش معنسى (FACT)

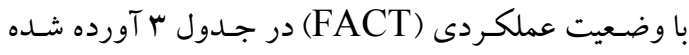

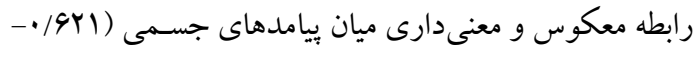

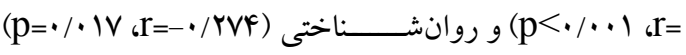

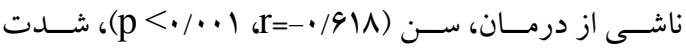


جدول r. مقايسه ميانكين ييامدها قبل و بعد از جراحى در بيماران مبتلا به سرطان كبد

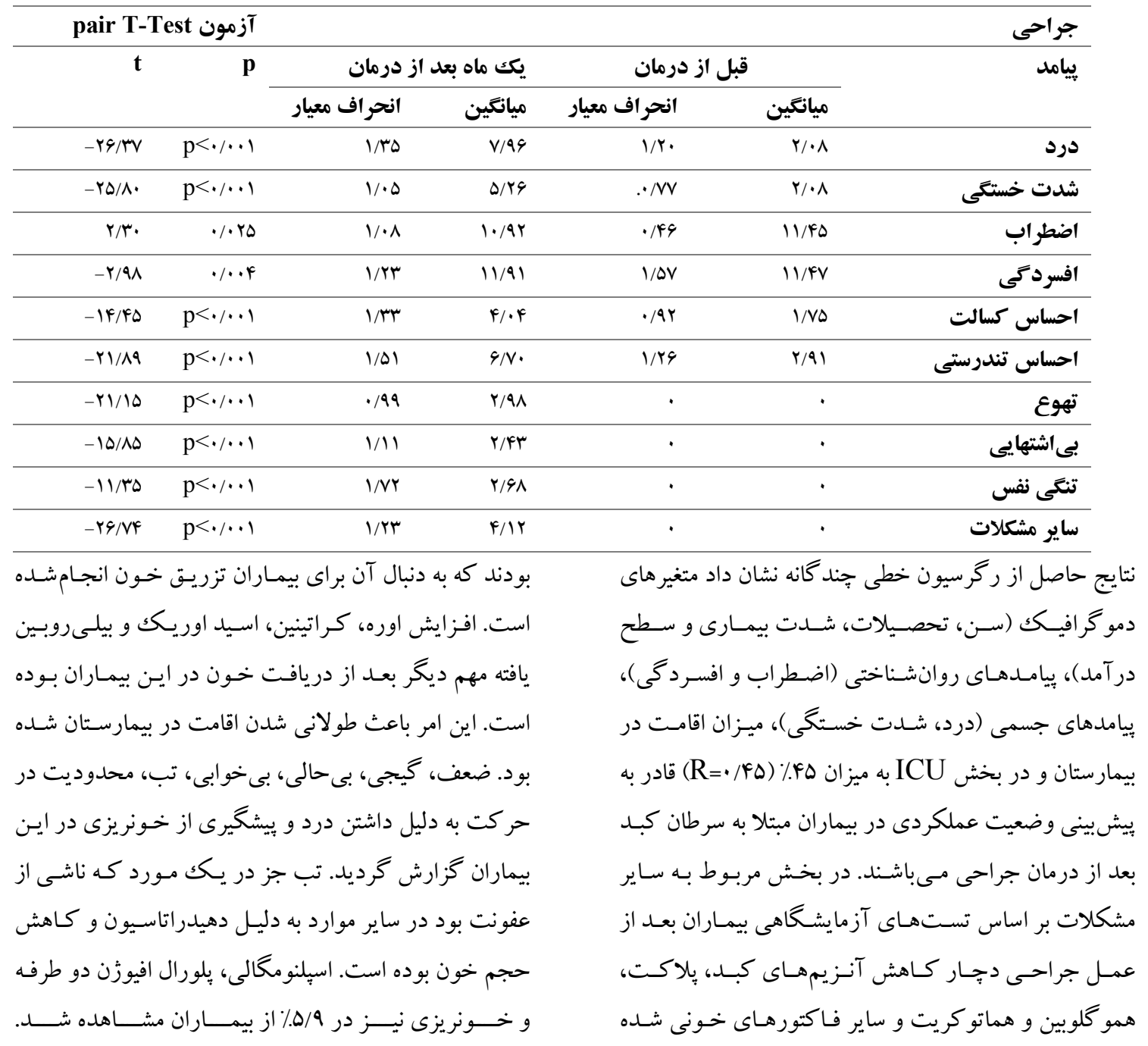

جدول r. ارتباط ميان ييامدهاى جسمى، روانشناختى و ويثكى هاى دمو كرافيك با وضعيت عملكردى (FACT) بيماران مبتلا به سرطان كبد

\begin{tabular}{|c|c|c|}
\hline \multicolumn{2}{|c|}{ وضعيت عملكردى(FACT) } & \multirow[b]{2}{*}{ متغير } \\
\hline $\mathbf{r}$ & $\mathbf{P}$ & \\
\hline$-\cdot / 9 Y 1$ & $\mathrm{p}<\bullet / \cdots+1$ & ييامدهاى جسمى (ESAS) \\
\hline$-\cdot / \mathrm{FF}$ & $\mathrm{p}<\bullet / \cdots 1$ & شدت خستكى(FSS) \\
\hline$-\cdot / r V F$ & $\mathrm{p}=\cdot / \cdot \mathrm{lV}$ & اضطر اب و افسردىى (HADS) \\
\hline-.1911 & $\mathrm{p}<\bullet / \cdots 1$ & 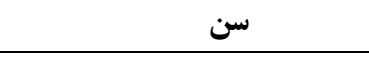 \\
\hline$\cdot / \mu F V$ & $\mathrm{p}=\cdot / \cdot \mathrm{rr}$ & درآمد \\
\hline$\cdot / T H V$ & $\mathrm{p}=\cdot / \cdot 1$ & تحصيلات \\
\hline$-\cdot / 90$ & $\mathrm{p}<\bullet / \cdot \cdot 1$ & شدت بيمارى \\
\hline
\end{tabular}


و همكاران (Y.IV) و همكاران (10 •r) در مطالعات خـود علائمم جسمانى را بـا شــايط نامناسـب روحسى -روانسى و كيفيـت بـايين زنـدكى

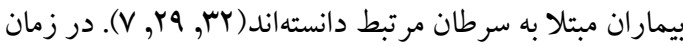
تكميل برسشنامهــا سؤالات زيـادى توسط بيمـاران مطرح

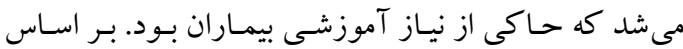

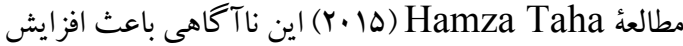

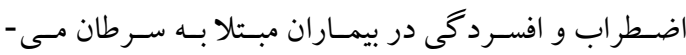
شود(بr). از اين رو آموزش و افزايش آحُاهى از نيـازهـاى اساسى بيماران بوده و بر اساس مطالعات بهترين و مهمترين دوره جهت ارائه آموزش، زمان تشخيص بيمارى، بسترى در بهر

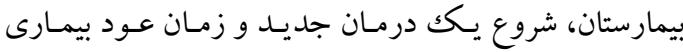
است. ايـن آمـوزشهـا مي توانـد بيرامـون بيمـارى، درمـان،

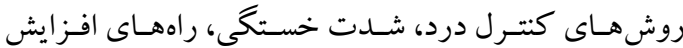
عملكرد و شيوههاى خودمر اقبتى باشد (TF).

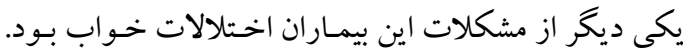

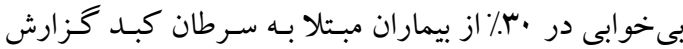
شد. اختلال خواب با مشكلات جسمى و روانشناختى رابطه

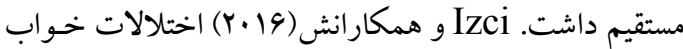

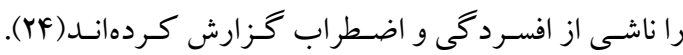
اكرجهه به دليل محدوديت زمانى در اين مطالعه زمان بِيخيرى

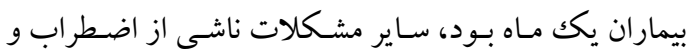
افسـرد گىى مشــاهده نشـــ امــا خود كشـى و آلكســيتيميا

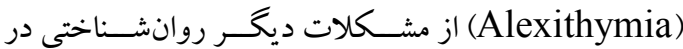

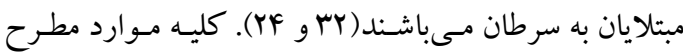

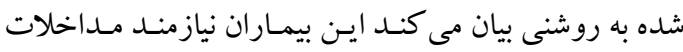

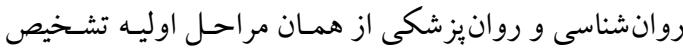
بيمارى مىباشند. لذا توصيه مى شود در كنار اقدامات درمانى رهي



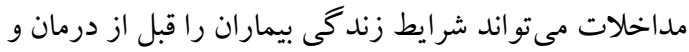

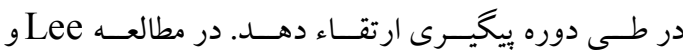

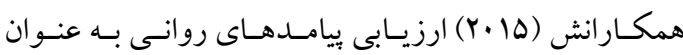

نتايج حاصل از اين مطالعه نشان داد بيماران مبتلا بـه سـرطان

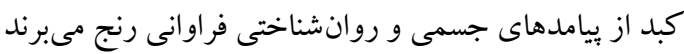
كه شامل درد، خستخى، بى اشتهايى، احساس كسالت، فقدان

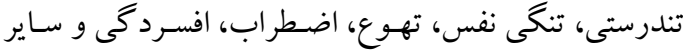

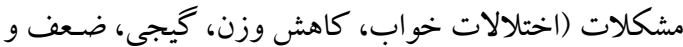
بى حسالى، كـاهش فاكتورهـاى خهونى، افزايش آنزيمهـاى كبدى و بيليروبين) است. همجنين نتايج حاصل از اين مطالعه

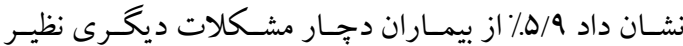
افيوزن بيلور، اختلال در عملكرد كبد شدهانـد كـه بـا مطالعهـ

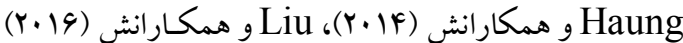

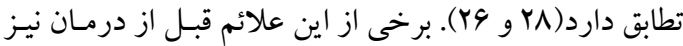

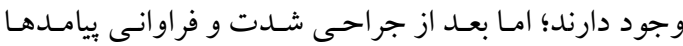

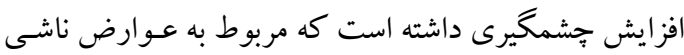

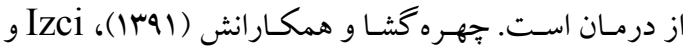
همكـارانش (19.19) بيامــدهـاى جسـمى و روانشـناختى را ناشى از سرطان و درمانهاى آن دانستهاند كه با نتايج حاصل از اين مطالعه مطابقت دارد(Y (Y • (Y). با وجود انتشار گايدلاين هاى مراقبتهاى روانى در بيمـاران مبـتلا بــه ســـرطان در ســال 1999 اشناســايى مشــكلات روانشناختى به دليل عدم غربال گرى مناسب كارى دشوار

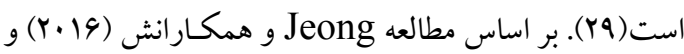
و و همكار انش (هee

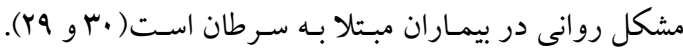

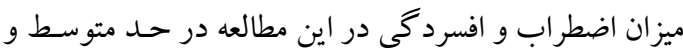

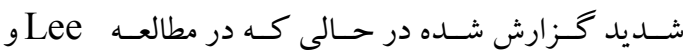

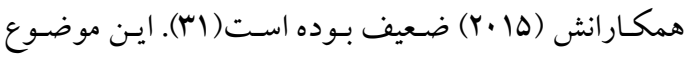

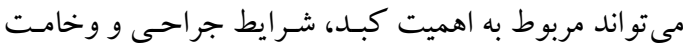
شرايط روحى -روانى در اين بيماران باشـــ. مردانى حموله و

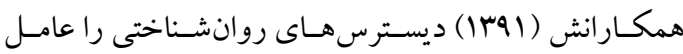
كليدى در بروز و ايجاد درد ناشى از سرطان معرفى كردهاند

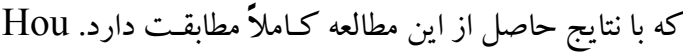


نتـايج حاصـل از ايسن مطالعـه نشـان داد بيامـدهـاى جسـمى، روان شناختى و برخى ويز گیىهاى دمو گر افيكك (سن، جنس، سـطح در آمـد، تحصسيلات و شــدت بيمـارى) بـا وضـعيت عملكردى ارتبـاط دارنـــــــا افز ايش سـن ميـزان بيامـدهـاى جسمى و روانشناختى افزايش يافتهه و وضسعيت عملكردى كاهش مى يابد؛ بنابر اين بيماران در سـنين بـالاتر نيازمند مراقبت هاى جسمانى بيشترى نسبت به افر اد جـوانتر هستـند. ايسن نتـايج بـا مطالعـه Mikoshiba و همكـار انش

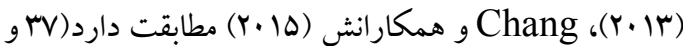

همجينين نتايج حاصل از اين مطالعه نشان داد ه/ه٪٪ از بيماران

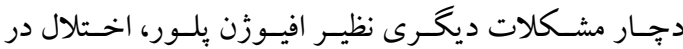
عملكرد كبد شدهاند كـه بـا مطالعـه Haung و همكـار انش Liu ، و همكارانش (Y. I (Y)

\section{نتيجل كيرى}

دو اصـل مهـم در بيمـاران مبـتلا بـه سـرطان كبــ حمايست و بررسىهاى جسمى و روانشـناختى اسـت كـه در تمـام دوره بيمارى بايد مورد توجه قرار گيرد. بيمـاران مبـتلا بـه سـرطان كبد بعد از عمل جراحى از مشكلات جسمى و روانشناختى


آنجايى كه شدت بيامدهـاى جسـمى بـه ويـزه درد و شـدت

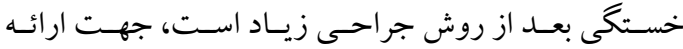
مراقبتهاى قبل و بعد از عمل تمر كز بيشـترى بـر روى ايسن

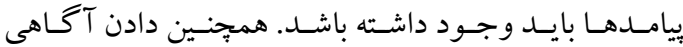
بير امــون بيامــدهــاى ناشـى از درمــان و مـــت اقامـت در

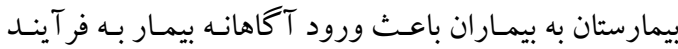
درمان مىشود. ورود آكاهانه به فر آيند درمان در بسـيارى از موارد انتظار وقوع اين ييامدها را براى بيمار ان همـوار سـاخته كه خود باعث ايجاد آمادگى مناسب در بيماران جهت مقابله با بيامدها مى شود. از سوى ديخر در بسيارى از مـوارد باعـث كاهش ميزان اضطراب و افسردگى آنها خو اهد شد. به دليل محدوديت زمانى در انجام يزّوهش امكان بيخيرى طـولانى -
ششمين علامت حياتى مطرح شده است كه بايد ماننـد سـاير علائم حياتى (نبض، فشار خون، درجه حرارت) مورد توجـه

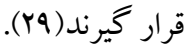

بر اساس نتايج حاصل از اين مطالعه مشـخص شـد وضـعيت

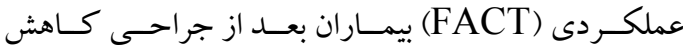
جشمخيرى داشته است. اين كاهش ناشى از مشكلاتى جــون درد، خستخگى، اضـطر اب ناشـى از جراحسى، احتمـال بـروز عوارض جانبى نظير خونريزى، افزايش سن، درآمد ناكافى و سوء تغذيه است. بيش از VV٪ بيماران شركت كنتـده در ايسن مطالعه درآمد ناكافى داشته و در بسـيارى از مـوارد از ميززان هزينههــاى درمـانى شـكايت داشـتند. شـرايط فيزيكى نظيـر وجود درن، سوند فولى، يوشيدن لباس ويثزه جهت بيشخيرى از خــونريزى باعـث افـزايش محســـوديت در ايسن بيمــاران مىشود كه در ساير روشهـاى درمـانى سـرطان كبـد وجـود ندارد. بر گشت بيمار ان به فعاليـتهـاى فـردى و اجتمـاعى بـا يكك تأخير جند ماهه امكانيذير است و اين بيمـاران نيازمنـد يكك دوره طولانى نقاهت در مقايسه با ساير بيماران مبـتلا بـهـ سرطان كبـد مس باشـند. كـاهش و رفع درد، سـاير عـوارض جسمى (كه باعث ايجاد محدوديتهاى حر كتى مىشـوند)، بازتوانى، كاردرمانى، حمايتهاى مالى، گسترش سيستمهاى حمايتى و افزايش آكَاهى مسى توانــ جهـت ارتقــاء عملكـرد بيماران و كاهش اضطراب و افسردگى آنها مؤثر باشد.

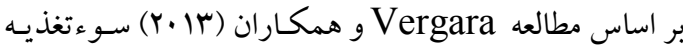

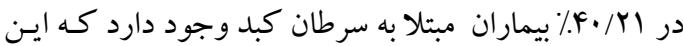
امر مربوط به نقش كبد در فعاليتهاى كوارشسى اسـت. ايسن شـر ايط باعـث افز ايش شـدت خستخى و كـاهش عملكـرد مىشود(Yr). با توجه با اينكه ايـن شـرايط قابـل بيشـيرى و كنترل مى باشند حمايتهاى تغذيهاى بايـــ بـه يـك هـدف و و اسـتراتزى مهــم در بيمـار ان مبـتلا بـه سـرطان كبـــ تبـديل

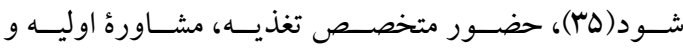
ييخيرىهاى دورهاى از اصول اساسى در اين بيماران به شمار

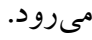




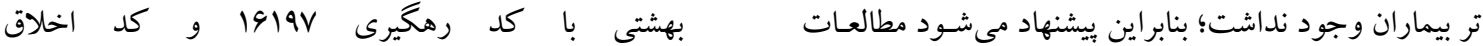

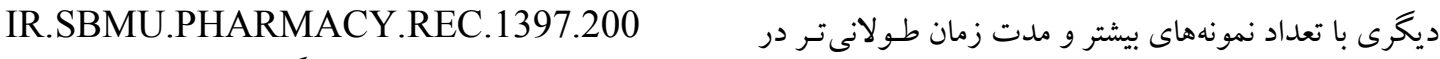

$$
\begin{aligned}
& \text { است. از كليه مشاركت كند كان تحقيق بابت ارائه تجارب } \\
& \text { ارزشمند خود قدردانى مى خردد. } \\
& \text { بيماران تحت درمان به روش جر احى انجام شود. }
\end{aligned}
$$

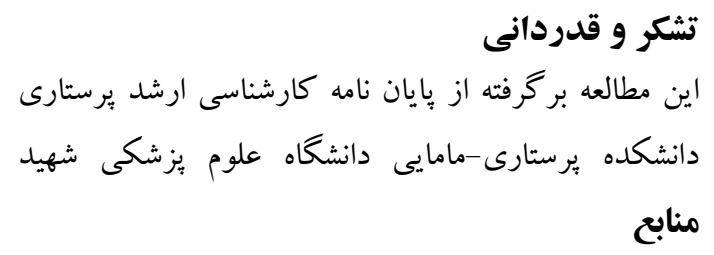

1.Khalili Parapary Y, Heidarzadeh M, Mozafari N. Translation and Psychometrics of Edmonton Symptom Assessment Scale. J Health \& Care. 2017;19(3):136-146.

2.Hasanvand S, Ashktorab T, Jafari Z, Salmani N, Safariyan Z. Cancer Related Fatigue and its Association with Health Related Quality of Life. J Nurs \& Midwifery. 2015;24(85):21-30. 3.Mardanihamooleh M, Borimnejad L, Seyedfatemi N, Tahmasebi M. Palliative Care of Pain in Cancer: Content Analysis. J Anesthesia \& Pain. 2013;4(1):55-63.

4.Ho CM, Hasegawa K, Chen X, Nagano H, Lee YJ, Chau GY. Surgery for Intermediate and Advanced Hepatocellular Carcinoma. J Hepatology. 2016;5(9):245-56.

5.Balogh J, David Victor III EHA, Burroughs SG, Boktour M, Saharia A, Li X, et al. Hepatocellular Carcinoma: A Review. J Hepatocellular Carcinoma. 2016;3(5):41-52.

6.Fazeli Z, Abdi R, Taghinejad MA. Studying of Liver Cancer Mortality and Morbidity Burden in Ilam, Iran. J Scientific Res. 2012;1(2):24-31.

7.Hou WK, Lau KM, Ng SM, Cheng ACK, Shum TCY, Cheng St, et al. Savoring Moderates the Association between Cancer Specific Physical Symptoms and Depressive Symptoms. J Psycho oncology. 2017;26(2):231-8.

8.Afzali F, Montazeri M, Heidari Z,Ahmadiyan L, Zahedi MJ. Futures Studies in Health: Choosing the Best Intelligent Data Mining Model to Predict and Diagnose Liver Cancer in Early Stage. J Health \& Biomedical Research. 2015;2(3):133-140.

9.Kudo M. Surveillance, Diagnosis, Treatment, and Outcome of Liver Cancer in Japan. Liver Cancer. 2015;4(1):39-50.

10.Breslin TM, Waldinger M, Silver SM. University of Michigan Comprehensive Cancer Center Opportunities for Improvement Project. J National Comprehensive Cancer Network. 2014;12(1):190-202.

11.Rezaei N, Far FF, Khademiureh S, Sheidaei A, Gohari K, Delavari F, et al. Liver Cancer Mortality at National and Provincial Levels in Iran between 1990 and 2015: A Meta Regression Analysis. Hepatitis Monthly. 2018;18(1):112-123.

12.Abachizadeh k, Keramatinia A. Anticipating Cancer Rate in Iran in 2025. Social Determinate of Health Research Center of Shahid Beheshti University of Medical Sciences. 2015;3(1):66-73.

13.Himoto T, Kurokohchi K, Watanabe S, Masaki T. Recent Advances in Radiofrequency Ablation for the Management of Hepatocellular Carcinoma. Hepatitis monthly. 2012;12(10):101-112.

14.Nishikawa H, Kimura T, Kita R, Osaki Y. Radiofrequency Ablation for Hepatocellular Carcinoma. International. Hyperthermia. 2013;29(6):558-68. 


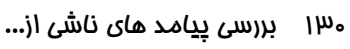

15.Ahn MH, Park S, Lee HB, Ramsey CM, Na R, Kim SO, et al. Suicide in cancer patients within the first year of diagnosis. Psycho Oncology. 2015;24(5):601-607.

16.Fan SY, Eiser C. Illness Experience in Pateint with Hepatocellular Carcinoma: An Interpretative Phenomenological Analysis Study. Gastrology \& Hepatology. 2012;24:203208.

17.Li L, Yeo W. Value of Quality of Life Analysis in Liver Cancer: A Clinician's Perspective. WJH. 2017;9(20):867-878.

18.Toro A, Pulvirenti E, Palermo F, Di Carlo I. Health Related Quality of Life in Patients with Hepatocellular Carcinoma after Hepatic Resection, Transcatheter Arterial Chemoembolization, Radiofrequency Ablation or no Treatment. Surgical oncology. 2012;21(1):23-30.

19.Ahmed S, Qiao W, Kasai M, Shelat VG. Quality of ife in hepatocellular carcinoma patient treated with transarterial chemoembolization. HPBS. 2016;12(3):212-220.

20.Chehrehgosha M, Dastourpour M, Sanagu A, Mohamadi A. Cancer Related Fatigue and its Relationship with Demographic and Clinical Characteristics. Golestan University of Medical Sciences. 2013;1(2):24-31.

21.Salehifar E, Hazeghpasand R, Keyhanian S, Ala S, Ahangar N. Evaluating pain management among cancer patients in a chemotherapycCenter. Mazandaran University of Medical Sciences. 2017;27(150):89-97.

22.Vergara N, Montoya JE, Luna HG, Amparo JR, Cristal-Luna G. Quality of life and nutritional status among cancer patients on chemotherapy. Oman Medical J. 2013;28(4):270.

23.Zhang TT, Luo HC, Cui X, Zhang W, Zhang LY, Chen XP, et al. Ultrasound Guided Percutaneous Microwave Ablation Treatment of Initial Recurrent Hepatocellular Carcinoma after Hepatic Resection: Long term Outcomes. Ultrasound in Medicine \& Biology. 2015;41(9):2391-9.

24.Izci F, Ilugn AS, Finkikli E, Ozmen V. Psychiatric Symptoms and Psychosocial Problem in Patient with Brest Cancer. J Brest Cancer. 2016;12(3):94-101.

25.Sajadian AS, Doganeeifard A, Behbuodi F. Psychotherapy and its Effect on Reducing Anxiety and Depression in Women with Breast Cancer. J Breast Diseases. 2016;9(2):43-51.

26.Huang G, Chen X, Lau W, Shen F, Wang RY, Yuan SX, et al .Quality of Life after Surgical Resection Compared with Radiofrequency Ablation for Small Hepatocellular Carcinomas. BJS. 2014;101(8):1006-15.

27.Kaviani H, Seyfourian H, Sarifi V, Ebrahimkhani N. Reliability and Validity of Anxiety and Depression Hospital Scales (HADS):Iranian patients with anxiety and depression disorders. Tehran University Medical J. 2009;67(5):379-85.

28.Liu H, Wang ZG, Fu SY, Li AJ, Pan ZY, Zhou WP, et al. Randomized Clinical Trial of Chemoembolization Plus Radiofrequency Ablation Versus Partial Hepatectomy for Hepatocellular Carcinoma within the Milan Criteria. BJS. 2016;103(4):348-56.

29.Lee BO, Choi WJ, Sung NY, Lee SK, Lee CG, Kang JI. Incidence and Risk Factors for Psychiatric Comorbidity Among People Newly Diagnosed with Cancer Based on Korean national registry data. Psycho Oncology. 2015;24(12):1808-14.

30.Jeong A, Shin DW, Kim SY, Yang HK, Park JH. Avoidance of Cancer Communication, Perceived Social Support, and Anxiety and Depression Among Patients with Cancer. Psycho Oncology. 2016;25(11):1301-1307.

31.Lee YH, Hsu CY, Chu CW, Liu PH, Hsia CY, Huang YH, et al. Radiofrequency Ablation Is Better than Surgical Resection in Patients with Hepatocellular Carcinoma within the Milan 
Criteria and Preserved Liver Function: A Retrospective Study Using Propensity Score Analyses. Gastroenterology. 2015;49(3):242-9.

32.Palmieri VO, Santovito D, Margari F, Lozupone M, Minerva F, Di Gennaro C, et al. Psychopathological profile and health-related quality of life (HRQOL) in patients with hepatocellular carcinoma (HCC) and cirrhosis. Clinical and Experimental Medicine. 2015;15(1):65-72.

33.Hamza Taha S, Mohamed WY, Sayed FA-z. Impact of a Designed Nursing Intervention Protocol on Quality of Life for Liver Cirrhosis Patients in Minia University Hospital. IOSRJNHS. 2015;4(4):7-15.

34.Shih WMJ, Hsiao PJ, Chen ML, Lin MH. Experiences of Family of Patient with Newly Diagnosed Advanced Terminal Stage Hepatocellular Cancer. APJC. 2013;14(8):55-60.

35.Kim HJ, Chu H, Lee S. Factors Influencing on Health Related Quality of Life in South Korean with Chronic Liver Disease. Health \& outcomes. 2018;16(1):142-149.

36.Chang $\mathrm{CH}$, Chen SJ, Liu CY. Risk of Developing Depressive Disorders Following Hepatocellular Carcinoma: a Nationwide Population based study. PLOS. 2015;10(8):e0135417.

37.Mikoshiba N, Miyashita M, Sakai T, Tateishi R, Koike K. Depressive Symptoms After Treatment in Hepatocellular Carcinoma Survivors: drevalence, determinants, and impact on health related quality of life. Psycho Oncology. 2013;22(10):47-53. 